Tropical Journal of Pharmaceutical Research March 2017; 16 (3): 573-576

ISSN: $1596-5996$ (print); 1596-9827 (electronic)

(C) Pharmacotherapy Group, Faculty of Pharmacy, University of Benin, Benin City, 300001 Nigeria.

All rights reserved.

Available online at http://www.tjpr.org

Original Research Article

http://dx.doi.org/10.4314/tjpr.v16i3.10

\title{
Effect of Ecklonia kurome extract on thyroid hormone disorder in rats
}

\author{
Wen-bo Zhang ${ }^{1}$, Ju-jin Li $^{2}$, Hui Zhang ${ }^{1}$ and Hong-wei Jiang ${ }^{1 *}$ \\ ${ }^{1}$ Division of Endocrinology, ${ }^{2}$ The Outpatient Office, The First Affiliated Hospital, and Clinical Medical College of Henan \\ University of Science and Technology, Luoyang 471300, Henan Province, China
}

*For correspondence: Email: jianghongwei494@sina.com; Tel: +86 0379-64815831

Received: 4 July 2016

Revised accepted: 12 February 2017

\begin{abstract}
Purpose: To investigate the effect of Ecklonia kurome extract (EKE) on thyroid hormone concentrations in male mice.

Methods: Mice were administered EKE by gastric intubation for 15 days. PTU or L-T4 was set as positive control. Twenty-four hours after the last administration, all animals were sacrificed by cervical dislocation. Blood was collected and serum samples assayed for T3 and T4. Furthermore, the liver was removed for biochemical analysis.

Results: T3 and T4 serum levels in mice decreased after the administration of EKE. The relative potency of EKE was calculated in terms of percent increase or decrease in thyroid hormones. Compared with the control value, the decrease in T3 concentration by a high dose of EKE was approximately $64.32 \%$. Compared with the control group, hepatic LPO decreased $(p<0.01)$ while superoxide dismutase $(S O D, p<0.01)$ and catalase $(C A T, p<0.01)$ activities were significantly increased by the high dose of EKE, thus indicating its anti-peroxidative role.

Conclusion: This suggests that EKE may be useful for the treatment of hyperthyroidism, but further studies are required to ascertain this.
\end{abstract}

Keywords: Ecklonia kurome, Thyroid hormone, Anti-peroxidative, Hyperthyroidism

Tropical Journal of Pharmaceutical Research is indexed by Science Citation Index (SciSearch), Scopus, International Pharmaceutical Abstract, Chemical Abstracts, Embase, Index Copernicus, EBSCO, African Index Medicus, JournalSeek, Journal Citation Reports/Science Edition, Directory of Open Access Journals (DOAJ), African Journal Online, Bioline International, Open-J-Gate and Pharmacy Abstracts

\section{INTRODUCTION}

Two thyroid hormones (thyroxine [T4] and triiodothyronine [T3]) are involved in the regulation of a myriad of body functions including lipid and carbohydrate metabolism, oxygen consumption, nerve conduction and reproduction [1]. Alterations in their normal levels lead to physiological/clinical abnormalities such as hypothyroidism and hyperthyroidism.

Despite the fact that day-by-day herbal drugs are gaining much importance due to its affordable and safe nature, scientific investigations towards the mitigation of thyroid disorders via plant extracts are meager [2-4]. Therefore, in our endeavor to determine a plant extract that can regulate the levels of both thyroid hormones, we have investigated the potential activities of Ecklonia kurome on thyroid functions. Traditional Chinese medicine has many advantages in treating metabolic disease. Ecklonia kurome is a common herb usually used for treating thyroid disease.

In this study, the effect of EKE on the efficacy of thyroid function was investigated. Hepatic lipid peroxidation (LPO), superoxide dismutase (SOD) and catalase (CAT) activities were also studied. 


\section{EXPERIMENTAL}

\section{Plant material and extraction}

Ecklonia kurome samples were collected from Qingdao City, Shandong Province, China in May 2016. Taxonomic identification of the plant was performed by Professor Liang Lu of Henan University of Traditional Chinese Medicine in China. A voucher specimen (no. EKE 20160503) was deposited in the herbarium of the College of Pharmacy, Henan University of Traditional Chinese Medicine, China for future reference.

The whole Ecklonia kurome plant was dried in a drying oven at $100^{\circ} \mathrm{C}$ for 12 hours. The Ecklonia kurome aqueous extract was obtained by steeping the dried Ecklonia kurome in water at $60{ }^{\circ} \mathrm{C}$ three times, each for one hour before first drying in an oven and freeze-drying the last extract. One gram of powder was obtained from approximately $1.6 \mathrm{~g}$ of dried sample; that is, a yield of $62.5 \%$.

\section{Animals and groups}

Colony-bred healthy Swiss albino male mice (30 $\pm 2 \mathrm{~g}$ ) were purchased from the Experimental Animal Center of Henan Province (Certificate no. SYXK 2006-02), maintained at $27 \pm 1^{\circ} \mathrm{C}$ with a light/dark schedule (14 hours light/10 hours dark), and provided with food and water ad libitum. These mice were randomly assigned to six groups: normal control group, propylthiouracil (PTU, $3 \mathrm{mg} / \mathrm{kg}$ ) group, L-tyroxine (L-T4, 0.5 $\mathrm{mg} / \mathrm{kg}$ ) group, and various concentrations of Ecklonia kurome extract (EKE; 80, 160 and 320 $\mathrm{mg} / \mathrm{kg}$ ) group.

The animals were administered EKE, PTU, or LT4 by gastric intubation. All the treatments were given twice daily and continued for 15 days. The experiment was approved by the Animal Care and Use Committee of Henan University of Science and Technology (Approval ref. no. 20101005) and was carried out in compliance with Directive 2010/63/EU on the handling of animals used for scientific purposes [5].

\section{Sample preparation}

On the last day of the experiment, mice were sacrificed by cervical dislocation. Blood was collected and serum samples were stored at -80 ${ }^{\circ} \mathrm{C}$ for one day until assayed for T3 and T4. The liver was quickly removed and washed thoroughly with phosphate-buffered saline (PBS, $\mathrm{pH}$ 7.4) for biochemical index analysis.

\section{Biochemical assays}

LPO was estimated by TBA reaction with malondialdehyde (MDA), a product formed due to the peroxidation of membrane lipids, according to the method performed by Ohkawa et al [6], and as modified by Jamall and Smith [7]. LPO was expressed as nM of MDA formed as per $\mathrm{h} / \mathrm{mg}$ of protein. Hepatic SOD activity was assayed according to the method reported by Marklund and Marklund [8]. Enzyme activity was expressed as units $/ \mathrm{mg}$ of protein, and one unit of enzyme is defined as the activity that inhibits the autoxidation of pyrogallol by $50 \%$. CAT activity was estimated following the method reported by Aebi [9].

\section{Determination of thyroid hormones}

Serum concentrations of total T3 and T4 were estimated by radioimmunoassay, as per routine protocol. Lower limits of sensitivity for T3 and T4 were 0.07 and $0.12 \mathrm{ng} / \mathrm{mL}$, respectively. Interassay variation was $<5 \%$ for both hormones.

\section{Statistical analysis}

All the data were analyzed using Statistical Package SPSS 16.0 (SPSS Inc., Illinois, Chicago, USA) and were expressed as mean \pm standard error of the mean (SEM). These data were analyzed by one-way analysis of variance (ANOVA) followed by Dunnett's $t$-test. A $p$-value $<0.05$ was considered statistically significant.

\section{RESULTS}

\section{Effect of EKE on serum concentrations of T3 and T4}

Compared with the control value, serum T3 and T4 concentrations in mice significantly decreased when treated by middle and high doses of EKE $(p<0.05)$, while serum T3 and T4 concentrations of mice significantly decreased when treated by middle and high doses of EKE $(p<0.01)$. Thyroid hormone concentrations also decreased in PTU and increased in T4 treated groups ( $p$ $</ 0.01$, for all groups).

When relative potencies of different doses of EKE with respect to control values were calculated, the maximum inhibition in T3 concentration was observed by a high dose of EKE $(64.32 \%)$, followed by a middle dose of EKE (32.43\%); while T4 was inhibited by 32.67 $\%$ by a high dose of EKE. Middle doses of EKE increased T4 concentrations by $15.41 \%$ (Table 1). 
Table 1: Effect of Ecklonia kurome extract on serum concentrations of T3 and T4

\begin{tabular}{lccccc}
\hline Group & $\begin{array}{c}\text { Dose } \\
\text { (mg/kg) }\end{array}$ & $\begin{array}{c}\text { T3 } \\
\text { concentration } \\
\text { (nmol/l) }\end{array}$ & $\begin{array}{c}\text { T4 } \\
\text { concentration } \\
\text { (nmol/l) }\end{array}$ & $\begin{array}{c}\text { Change in T3 } \\
\text { concentration } \\
\text { (\%) }\end{array}$ & $\begin{array}{c}\text { Change in T4 } \\
\text { concentration } \\
\text { (\%) }\end{array}$ \\
\hline Control & - & $1.85 \pm 0.14$ & $42.12 \pm 2.5$ & - & - \\
EKE-L & 80 & $1.63 \pm 0.21$ & $40.27 \pm 3.3$ & -11.89 & -4.39 \\
EKE-M & 160 & $1.21 \pm 0.15$ & $35.63 \pm 1.5$ & -32.43 & -15.41 \\
EKE-H & 320 & $0.66 \pm 0.12$ & $28.36 \pm 1.1^{\text {n }}$ & -64.32 & -32.67 \\
PTU & 3 & $0.61 \pm 0.07^{\pi \times}$ & $16.34 \pm 0.89$ & -67.03 & -61.21 \\
$\mathrm{~T}_{4}$ & 0.5 & $2.67 \pm 0.15^{\pi \times}$ & $104.59 \pm 7.38$ & +44.32 & +148.31 \\
\hline
\end{tabular}

EKE-L: Iow dose of EKE; EKE-M: middle dose of EKE; EKE-H: high dose of EKE. "P<0.01, $p<0.05$, compared to the respective controls

Table 2: Effect of Ecklonia kurome extract on hepatic LPO, CAT and SOD activities in male mice

\begin{tabular}{|c|c|c|c|c|}
\hline Group & $\begin{array}{c}\text { Dose } \\
(\mathrm{mg} / \mathrm{kg})\end{array}$ & LPO (nM /mg protein) & $\begin{array}{l}\text { SOD (unit/mg } \\
\text { protein) }\end{array}$ & $\begin{array}{c}\text { CAT (mmol } / \mathrm{mg} \\
\text { protein) }\end{array}$ \\
\hline Control & - & $0.93 \pm 0.07$ & $4.88 \pm 0.18$ & $39.26 \pm 2.35$ \\
\hline EKE-L & 80 & $0.84 \pm 0.05$ & $5.12 \pm 0.23$ & $41.25 \pm 2.12$ \\
\hline EKE-M & 160 & $0.71 \pm 0.06^{\pi}$ & $6.36 \pm 0.21^{\star}$ & $45.18 \pm 1.95^{\pi}$ \\
\hline EKE-H & 320 & $0.52 \pm 0.04^{\pi \pi}$ & $8.34 \pm 0.17^{\pi \pi}$ & $57.24 \pm 1.84^{\pi \pi}$ \\
\hline PTU & 3 & $0.97 \pm 0.09$ & $4.92 \pm 0.19$ & $25.33 \pm 3.62 \cong$ \\
\hline $\mathrm{T}_{4}$ & 0.5 & $2.37 \pm 0.19$ & $4.53 \pm 0.17$ & $34.12 \pm 3.27$ \\
\hline
\end{tabular}

EKE-L: Iow dose of EKE; EKE-M: middle dose of EKE; EKE-H: high dose of EKE. "P<0.01, $p<0.05$, compared to the respective control values

\section{Effect of EKE on hepatic LPO, CAT and SOD activities in male mice}

The hepatic LPO level of mice decreased when treated by high $(P</ 0.01)$ and middle $(P</ 0.05)$ doses of EKE. On the other hand, SOD and CAT activities were significantly enhanced in high dose EKE $(P<0.01)$ and middle dose EKE $(P<0.05$, for both) treated animals. In PTU treated animals, CAT activity was inhibited $(P<0.01$, Table 2$)$.

\section{DISCUSSION}

These results reveal that serum levels of both T3and T4 were inhibited by EKE. When the relative potency of EKE was calculated in terms of percent increase or decrease in thyroid hormones, as compared to the control value, the decrease in T3 concentration through high doses of EKE was approximately $64.32 \%$. This indicates its possible use in the regulation of hyperthyroidism.

The predominant thyroidal hormone in circulation is T4, while T3 is mostly generated from T4 in peripheral tissues by outer ring monodeiodination $[10,11]$. Since only T4, and not T3, was enhanced by EKE, it appears that EKE might be stimulating the synthesis and/or release of T4 directly at the glandular level, and not through the peripheral conversion of T4 to T3. The former one appeared to have a better potency, as it could inhibit T3 by approximately $64.32 \%$; which is comparable to that of a standard drug, PTU. Although EKE decreased both T3 and T4 concentrations, the inhibition was only approximately 64 and $32 \%$, respectively. This indicate that EKE may not be very effective in the reduction of thyroid hormone concentrations. However, EKE may be a better choice for thyroid disease, as it does not exhibit any hepatotoxic effect, and is rather hepatoprotective in nature.

It was reported that LPO occurs in biological membranes with potential injurious consequences [12,13]. Anti-oxidative enzymes (SOD and CAT) usually help maintain cellular integrity by protecting it against the deleterious effects of lipid peroxides [14]. Interestingly no hepatotoxic effects were observed in EKE. The decrease in hepatic LPO with a concomitant increase in the activities of antioxidative enzymes (SOD and CAT) by EKE suggest its antiperoxidative nature.

\section{CONCLUSION}

EKE may augment thyroid function, and can potentially be developed as a therapeutic agent for the treatment of hyperthyroidism in the future.

\section{DECLARATIONS}

\section{Conflict of Interest}

No conflict of interest associated with this work. 


\section{Contribution of Authors}

The authors declare that this work was done by the authors named in this article and all liabilities pertaining to claims relating to the content of this article will be borne by them.

\section{Open Access}

This is an Open Access article that uses a funding model which does not charge readers or their institutions for access and distributed under the terms of the Creative Commons Attribution License (http://creativecommons.org/licenses/by 14.0) and the Budapest Open Access Initiative (http://www.budapestopenaccessinitiative.org/rea d), which permit unrestricted use, distribution, and reproduction in any medium, provided the original work is properly credited.

\section{REFERENCES}

1. Ganong WF. Review of medical physiology. Appleton and Lange, Connecticut 1995; 23: 290-305.

2. Winterhoff $H$, Sourgens $H$, Kemper FH. Antihormonal effects of plant extracts pharmacodynamic effects of Lithospermum officinale on the thyroid gland of rats: comparison with the effects of iodide. Hormone Metabol Res 1983; 15: 503-507.

3. Panda S, Kar A. Antithyroidal property of root extract of Shankapuspi (Convolvulus pluricaulis) in mice. Med SciRes 1997; 25: 677-678.

4. Panda S, Tahiliani P, Kar A. Inhibition of tri-iodothyronine production by Fenugreek seed extract in mice \& rats. PharmacolRes 1999; 40: 405- 409.
5. European Commission [homepage on the internet]. Directive 2010/63/EU on the protection of animals used for scientific purposes [cited 2013 Jan 16]. Available from:http://ec.europa.eu/environment/chemicals/lab_ani mals/legislation_en.htm.

6. Ohkawa H, Ohishi N, Yagi K. Assay of lipid peroxides in animal tissues by thiobarbituric acid reaction. Annal Biochem1979; 95: 351-358.

7. Jamall IS, Smith C. Effects of cadmium on glutathione peroxidase, superoxide dismutase and Lipid peroxidation in isolated rat hepatocytes. Toxicol Appl Pharmacol 1985; 80: 33-42.

8. Marklund $S$, Marklund $G$. Involvement of superoxide anion radical in the autoxidation of pyrogallol: a convenient assay for superoxide dismutase. Euro $J$ Biochem 1974; 47: 469-474.

9. Aebi H. Catalase. In: Bergmeyer $H$ (Ed). Methods in Enzymatic Analysis. Academic Press, New York, 1983; pp 276-286.

10. Chitra P, Sajithalal GB, Chandrakasan G. Influence of Aloevera on collagen turnover in healing of dermal wounds in rats. Ind J Experim Biol 1998; 36: 896-901.

11. Nath $D$, Sethi N, Singh RK, Jain AK. Commonly used Indian abort facient plants with special reference to their teratologic effects in rats. J Ethno Pharmacol 1992; 36 : 147-154.

12. Comporti M. Lipid peroxidation and cellular damage in toxic liver injury. Lab Investigation 1985; 53: 51-56.

13. Chopra RN, Chopra IC, Verma BS. Supplementary to Glossary of Indian medicinal plants. National Institute of Science Communication, Council of Scientific and Industrial Research, New Delhi 1998; 2: 10-11.

14. Seiss H. Strategies of antioxidant defense. Eur J Biochem 1993; 215: 213-219. 